\title{
Front Matter: Volume 9112
}

, "Front Matter: Volume 9112," Proc. SPIE 9112, Sensing Technologies for Global Health, Military Medicine, and Environmental Monitoring IV, 911201 (18 June 2014); doi: 10.1117/12.2074015

SPIE Event: SPIE Sensing Technology + Applications, 2014, Baltimore, MD, United SPIE. States 


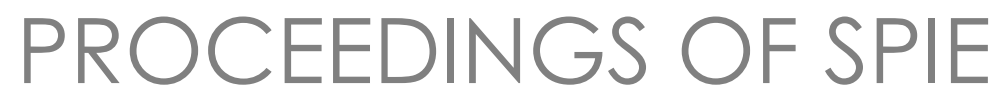

\title{
Sensing Technologies for Global Health, Military Medicine, and Environmental Monitoring IV
}

\author{
Šárka O. Southern \\ Mark A. Mentzer \\ Isaac Rodriguez-Chavez \\ Virginia E. Wotring \\ Editors
}

5-7 May 2014

Baltimore, Maryland, United States

Sponsored and Published by

SPIE 
The papers included in this volume were part of the technical conference cited on the cover and title page. Papers were selected and subject to review by the editors and conference program committee. Some conference presentations may not be available for publication. The papers published in these proceedings reflect the work and thoughts of the authors and are published herein as submitted. The publisher is not responsible for the validity of the information or for any outcomes resulting from reliance thereon.

Please use the following format to cite material from this book:

Author(s), "Title of Paper," in Sensing Technologies for Global Health, Military Medicine, and Environmental Monitoring IV, edited by Šárka O. Southern, Mark A. Mentzer, Isaac Rodriguez-Chavez, Virginia E. Wotring, Proceedings of SPIE Vol. 9112 (SPIE, Bellingham, WA, 2014) Article CID Number.

ISSN: 0277-786X

ISBN: 9781628410495

Published by

SPIE

P.O. Box 10, Bellingham, Washington 98227-0010 USA

Telephone +1 3606763290 (Pacific Time) · Fax +1 3606471445

SPIE.org

Copyright (C) 2014, Society of Photo-Optical Instrumentation Engineers.

Copying of material in this book for internal or personal use, or for the internal or personal use of specific clients, beyond the fair use provisions granted by the U.S. Copyright Law is authorized by SPIE subject to payment of copying fees. The Transactional Reporting Service base fee for this volume is $\$ 18.00$ per article (or portion thereof), which should be paid directly to the Copyright Clearance Center (CCC), 222 Rosewood Drive, Danvers, MA 01923. Payment may also be made electronically through CCC Online at copyright.com. Other copying for republication, resale, advertising or promotion, or any form of systematic or multiple reproduction of any material in this book is prohibited except with permission in writing from the publisher. The CCC fee code is 0277-786X/14/\$18.00.

Printed in the United States of America.

Publication of record for individual papers is online in the SPIE Digital Library.

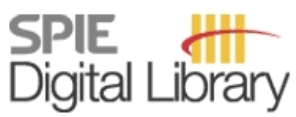

SPIEDigitalLibrary.org

Paper Numbering: Proceedings of SPIE follow an e-First publication model, with papers published first online and then in print and on CD-ROM. Papers are published as they are submitted and meet publication criteria. A unique, consistent, permanent citation identifier (CID) number is assigned to each article at the time of the first publication. Utilization of CIDs allows articles to be fully citable as soon as they are published online, and connects the same identifier to all online, print, and electronic versions of the publication. SPIE uses a six-digit CID article numbering system in which:

- The first four digits correspond to the SPIE volume number.

- The last two digits indicate publication order within the volume using a Base 36 numbering

system employing both numerals and letters. These two-number sets start with 00, 01, 02, 03, 04, $05,06,07,08,09,0 A, 0 B \ldots$. 0Z, followed by 10-1Z, 20-2Z, etc.

The CID Number appears on each page of the manuscript. The complete citation is used on the first page, and an abbreviated version on subsequent pages. Numbers in the index correspond to the last two digits of the six-digit CID Number. 


\section{Contents}

vii Conference Committee
ix Introduction

\section{NON-INVASIVE DISEASE DIAGNOSTICS FOR GLOBAL HEALTH I}

911203 Rapid non-invasive tests for diagnostics of infectious diseases [9112-71]

D. Malamud, New York Univ. (United States)

911206 Programmable bio-nano-chip system for saliva diagnostics [9112-7]

N. Christodoulides, Rice Univ. (United States); R. De La Garza II, Baylor College of Medicine (United States); G. W. Simmons, M. P. McRae, J. Wong, Rice Univ. (United States);

T. R. Kosten, Baylor College of Medicine (United States); C. S. Miller, J. L. Ebersole, Univ. of Kentucky (United States); J. T. McDevitt, Rice Univ. (United States)

$911208 \quad$ Next-generation confirmatory disease diagnostics [9112-73]

R. Lin, R. Gerver, K. Karns, A. A. Apori, A. K. Denisin, A. E. Herr, Univ. of California, Berkeley (United States)

NON-INVASIVE DISEASE DIAGNOSTICS FOR GLOBAL HEALTH II

9112 OB Human saliva proteome: an overview (Invited Paper) [9112-11]

T. J. Griffin, Univ. of Minnesota (United States)

9112 OD Experimental strategy to discover microbes with gluten-degrading enzyme activities [9112-10]

E. J. Helmerhorst, G. Wei, Boston Univ. (United States)

$91120 \mathrm{G}$ Serum and salivary cardiac analytes in acute myocardial infarction related to oral health status (Invited Paper) [9112-13]

J. L. Ebersole, R. J. Kryscio, C. Campbell, Univ. of Kentucky (United States); D. F. Kinane, Univ. of Pennsylvania (United States); J. T. McDevitt, N. Christodoulides, P. N. Floriano, Rice Univ. (United States); C. S. Miller, Univ. of Kentucky (United States)

\section{MILITARY MEDICINE I: TRAUMATIC BRAIN INJURY AND PTSD}

$91120 \mathrm{~J}$ The military's approach to traumatic brain injury and post-traumatic stress disorder (Invited Paper) [91 12-20]

G. S. F. Ling, J. Grimes, Uniformed Services Univ. of the Health Sciences (United States); J. M. Ecklund, Uniformed Services Univ. of the Health Sciences (United States) and Inova Fairfax Hospital (United States) 
9112 OL New approach to neurorehabilitation: cranial nerve noninvasive neuromodulation (CN-NINM) technology [9112-23]

Y. P. Danilov, M. E. Tyler, K. A. Kaczmarek, K. L. Skinner, Univ. of Wisconsin-Madison (United States)

MILITARY MEDICINE II: PHYSIOLOGY AND MEDICINE OF EXTREME ENVIRONMENTS AND SPACEFLIGHT

9112 OR Drug stability analyzer for long duration spaceflights [9112-26]

C. Shende, W. Smith, C. Brovillette, S. Farquharson, Real-Time Analyzers, Inc. (United States)

9112 OU Military target task performance after wavefront-guided (WFG) and wavefront-optimized (WFO) photorefractive keratectomy (PRK) [9112-34]

T. Maurer, D. Deaver, C. Howell, S. Moyer, O. Nguyen, G. Mueller, U.S. Army Night Vision \& Electronic Sensors Directorate (United States); D. Ryan, R. Sia, Warfighter Refractive Surgery and Research Ctr. (United States); R. Stutzman, J. Pasternak, Walter Reed National Military Medical Ctr. (United States); K. Bower, Johns Hopkins Univ. (United States)

9112 OV Raman spectroscopic analysis of whole blood acetylcholinesterase [9112-32] P. G. Wilcox, U.S. Army Edgewood Chemical Biological Ctr. (United States) and Johns Hopkins Univ. (United States); J. U. Kang, Johns Hopkins Univ. (United States)

9112 OW The challenges of analysing blood stains with hyperspectral imaging [91 12-35] J. Kuula, H.-H. Puupponen, H. Rinta, I. Pölönen, Univ. of Jyväskylä (Finland)

SENSING TECHNOLOGIES FOR DISEASE DIAGNOSTICS AND ENVIRONMENTAL MONITORING II

911211 Portable capillary electrophoresis-system for on-site food analysis with lab-on-a-chip based contactless conductivity detection (Invited Paper) [91 12-38]

C. Gärtner, R. Sewart, R. Klemm, H. Becker, microfluidic ChipShop GmbH (Germany)

911212 Critical stages of a biodetection platform development from sensor chip fabrication to surface chemistry and assay development [9112-39]

Y. Uludag, TÜBITAK BILGEM (Turkey)

911213 Chemoselective surface attachment of antimicrobial peptides and its effects on interfacial behavior [9112-40]

S. H. North, C. So, K. Fears, C. R. Taitt, U.S. Naval Research Lab. (United States)

911216 Software system for computing material and structural properties of bone and muscle in the lower extremity from PQCT [91 12-43]

S. Makrogiannis, Delaware State Univ. (United States) and National Institutes of Health

(United States); L. Ferrucci, National Institutes of Health (United States) 
911217 Label-free single cancer marker protein detection using a nanoplasmonic-photonic hybrid whispering gallery mode biosensor [9112-44]

S. Holler, Fordham Univ. (United States); V. R. Dantham, D. Keng, Polytechnic Institute of New York Univ. (United States); V. Kolchenko, New York City College of Technology (United States); S. Arnold, Polytechnic Institute of New York Univ. (United States)

911218 Miniature Fabry-Perot sensor with polymer dual optical cavities for simultaneous pressure and temperature measurements [9112-45]

H. Bae, M. Yu, Univ. of Maryland, College Park (United States)

911219 Prototype spectral analysis of water samples for monitoring and treatment of public water resources (Invited Paper) [9112-46]

S. G. Lambrakos, M. Lee, U.S. Naval Research Lab. (United States); C. Yapijakis, The Cooper Union (United States); L. S. Ramsey, L. Huang, U.S. Naval Research Lab. (United States);

A. Shabaev, George Mason Univ. (United States); L. Massa, Hunter College (United States)

$91121 \mathrm{~A} \quad$ Estimation of suspended sediment concentrations from remotely sensed spectral reflectance: a field calibration for the Yellow River (Invited Paper) [9112-47]

L. Qu, D. Civco, Univ. of Connecticut (United States); T. Lei, China Agricultural Univ. (China);

$X$. Yang, Univ. of Connecticut (United States)

\section{POSTER SESSION}

9112 1C Environmental data analysis and remote sensing for early detection of dengue and malaria [9112-31]

M. Z. Rahman, LaGuardia Community College (United States); L. Roytman, The City College of New York (United States); A. Kadik, LaGuardia Community College (United States); D. A. Rosy, Univ. of Dhaka (Bangladesh)

9112 1D Simulation studies in biochemical signaling and enzyme reactions [91 12-49]

S. R. Nelatury, Penn State Erie, The Behrend College (United States); M. C. Vagula, Gannon Univ. (United States)

$91121 \mathrm{E}$ Radiation hazards of radio frequency waves on the early embryonic development of Zebrafish [91 12-50]

R. Harkless, M. Al-Quraishi, M. C. Vagula, Gannon Univ. (United States)

$91121 \mathrm{~F} \quad$ Remote laser spectroscopy of oil and gas deposits [9112-51]

A. P. Zhevlakov, V. G. Bespalov, V. V. Elizarov, A. S. Grishkanich, S. V. Kascheev, E. A. Makarov, S. A. Bogoslovsky, National Research Univ. of Information Technologies, Mechanics and Optics (Russian Federation); A. A. Il'inskiy, All Russian Petroleum Research Exploration Institute (Russian Federation)

$9112 \mathrm{1H} \quad$ Analysis of a generalized model for influenza including differential susceptibility due to immunosuppression [9112-53]

D. Hincapié, Univ. de Antioquia (Colombia); J. Ospina, Univ. EAFIT (Colombia)

911211 Using computer algebra and SMT-solvers to analyze a mathematical model of cholera propagation [9112-54]

M. Trujillo Arredondo, Univ. EAFIT (Colombia) 
$91121 \mathrm{~J}$ Computational algebraic geometry of epidemic models [9112-55]

M. Rodríguez Vega, Univ. EAFIT (Colombia)

$91121 \mathrm{~K} \quad$ Using Tutte polynomials to characterize sexual contact networks [9112-56]

J. J. Cadavid Muñoz, Univ. EAFIT (Colombia)

$91121 \mathrm{~L} \quad$ Computing $R_{0}$ in a population with heterogeneity in sexual activity and proportionate mixing using a STM-solver [91 12-57]

N. A. Gutierrez A., Univ. EAFIT (Colombia)

$91121 \mathrm{M} \quad$ Bessel filters applied in biomedical image processing [9112-58]

J. P. Mesa López, D. L. Castañeda Saldarriaga, Univ. EAFIT (Colombia)

$91121 \mathrm{~N} \quad$ Application of a Morse filter in the processing of brain angiograms [91 12-59]

S. Venegas Bayona, Univ. EAFIT (Colombia)

911210 Using special functions to model the propagation of airborne diseases [9112-60]

D. Bolaños, Univ. EAFIT (Colombia)

9112 1P Optimal control in a model of malaria with differential susceptibility [9112-61]

D. Hincapié, Univ. of Antioquia (Colombia); J. Ospina, Univ. EAFIT (Colombia)

$91121 Q \quad$ Using quantum filters to process images of diffuse axonal injury [9112-62]

M. Pineda Osorio, Univ. EAFIT (Colombia)

Author Index 


\section{Conference Committee}

Symposium Chair

David A. Whelan, Boeing Defense, Space, and Security

(United States)

Symposium Co-chair

Wolfgang Schade, Technische Universität Clausthal (Germany) and Fraunhofer Heinrich-Hertz-Institut (Germany)

Conference Chair

Šárka O. Southern, Gaia Medical Institute (United States)

Conference Co-chairs

Mark A. Mentzer, Neuroscience Applications Group, LLC (United States)

Isaac Rodriguez-Chavez, National Institute of Dental and Craniofacial Research (United States)

Virginia E. Wotring, Universities Space Research Association/NASA JSC (United States)

Conference Program Committee

James Delehanty, U.S. Naval Research Laboratory (United States)

Theresa G. Evans-Nguyen, Draper Laboratory (United States)

Peter Kiesel, Palo Alto Research Center, Inc. (United States)

Baochuan Lin, U.S. Naval Research Laboratory (United States)

Daniel Malamud, New York University (United States)

Igor Medintz, U.S. Naval Research Laboratory (United States)

Richard M. Ozanich, Pacific Northwest National Laboratory (United States)

Ava M. Puccio, University of Pittsburgh Medical Center (United States)

Steven A. Ripp, The University of Tennessee (United States)

Albert Skip Rizzo III, The University of Southern California (United States)

Kim E. Sapsford, U.S. Food and Drug Administration (United States)

Shadrian B. Strong, Johns Hopkins University Applied Physics Laboratory (United States)

David E. Wolf, Radiation Monitoring Devices, Inc. (United States)

Aurel Ymeti, Ostendum R\&D BV (Netherlands) 


\section{Session Chairs}

1 Non-invasive Disease Diagnostics for Global Health I

Šárka O. Southern, Gaia Medical Institute (United States)

Isaac R. Rodriguez-Chavez, National Institute of Dental and Craniofacial Research (United States)

Daniel Malamud, New York University (United States)

2 Non-invasive Disease Diagnostics for Global Health II

Timothy J. Griffin, University of Minnesota (United States)

Charles F. Streckfus, The University of Texas at Houston (United States)

Šárka O. Southern, Gaia Medical Institute (United States)

3 Military Medicine I: Traumatic Brain Injury and PTSD

Mary E. Michel, National Institutes of Health (United States)

Geoffrey Ling, Uniformed Services University of the Health Sciences (United States)

Barry D. Jordan, Sports Concussion Institute (United States)

4 Military Medicine II: Physiology and Medicine of Extreme Environments and Spaceflight

Virginia E. Wotring, Universities Space Research Association/NASA JSC (United States)

Jonathan D. Stallings, U.S. Army Center for Environmental Health Research (United States)

5 Sensing Technologies for Disease Diagnostics and Environmental Monitoring I

Stephen M. Hewitt, National Cancer Institute (United States)

Richard Conroy, National Institutes of Health (United States)

Šárka O. Southern, Gaia Medical Institute (United States)

6 Sensing Technologies for Disease Diagnostics and Environmental Monitoring II

Stephen M. Hewitt, National Cancer Institute (United States)

Claudia Gärtner, microfluidic ChipShop GmbH (Germany) 


\section{Introduction}

The 2014 SPIE Sensing Technologies for Global Health, Military Medicine, and Environmental Monitoring conference embraced a wealth of state-of-the-art information in basic and applied science. This event covered the latest developments in the following areas:

- Non-invasive Disease Diagnostics for Global Health - This opening series of two consecutive sessions focused on oral biospecimen based rapid assays and point-of-care devices for the detection of pathogens causing infectious diseases, biomarkers for cancer, and analytes for noncommunicable diseases such as diabetes. They also covered presentations on the human proteasome and microbiome with linkage to human diseases and diagnostic approaches. The sessions were built on the past experience and expertise of the National Institutes of Health, National Institutes of Dental and Craniofacial Research.

- Military Medicine I: Traumatic Brain Injury and PTSD-This assembly covered oral-biomarker based diagnostics for brain damage and TBI as well as prevention and rehabilitation technologies. Neurorehabilitation and noninvasive neuromodulation were also discussed as critical approaches for effective functioning.

- Military Medicine II: Physiology and Medicine of Extreme Environments and Spaceflight-This scientific segment showcased physiological, pharmacological and diagnostic sensing methodologies during spaceflight per the National Aeronautics and Space Administration as well as military-relevant toxicans and future sensing trends per the Department of Defense. It also included latest technologies to determine hydration status in warfighters, eye surgery using the latest laser technologies, and sensing tools for blood analysis.

- Sensing Technologies for Disease Diagnostics and Environmental Monitoring-This closing series of two consecutive sessions provided the venues to learn and discuss more results on the next generation of diagnostic tools and field technologies for diseases, including biomarker detection by digital imaging, multiplex technologies, capillary electrophoresis and molecular platforms serving as labs-on-chips.

This conference allowed cross-fertilization of ideas, projects and collaborative work by a multidisciplinary audience of national and international colleagues from the academia, industry and federal government: The National Institutes of Health, National Aeronautics and Space Administration, and the Department of Defense.

In 2015, this conference will enhance its focus on Global Health as an encompassing umbrella to include sensing technologies at early, medium and advanced level of development and implementation for communicable and non-communicable diseases impacting public and military health. 
The success of this conference lied in the compelling talks presented by distinguished speakers and the active and perceptive audience of colleagues who actively participated. The knowledge shared in this conference seeded projects that will translate into tangible and novel sensing tools to improve human health and quality of life. We look forward to enhancing the productivity and the success of this conference in 2015.

Šárka O. Southern Isaac Rodriguez-Chavez 